К. М. Анзіна, А. В. Гудзенко

\title{
Амінокислотний склад трави та коренів деяких перспективних рослин роду Teucrium L. флори України
}

Приватний вищий навчальний заклад «Київський медичний університет», м. Київ

Ключові слова: амінокислоти,

високоефективна рідинна хроматографія, рід Tеucrium L.

Потреба людини в рослинному білку, перш за все, пов'язана з важливістю надходження амінокислот. Наявність дефіциту принаймні однієї незамінної амінокислоти робить раціон харчування людини неповноцінним, що може стати причиною розвитку ряду патологічних станів організму [1-2].

у рослинах білки утворюються в процесі життєдіяльності за допомогою фотосинтезу з неорганічних сполук - це є їхньою відмінністю від організму людину, в якому не всі амінокислоти синтезуються. Частину амінокислот людський організм поповнює за рахунок виключно рослинної їжі [3-5].

Лізин необхідний для нормального формування кісток i росту дітей, сприяе засвоєнню кальцію та підтриманню нормального обміну азоту в дорослих.

Лейцин здатний впливати на секрецію інсуліну, збільшуючи його виділення, сприяє збільшенню синтезу білка [6-7].

Глутамінова кислота $є$ нейромедіатором, стимулює передачу імпульсів у синапсах центральної нервової системи.

Аспарагінова кислота забезпечує нейропротекторну функцію, бере участь у регуляторних процесах ендокринної системи [8-10].
Виходячи з цього, одним з актуальних питань сучасної фармації $\mathrm{e}$ пошук нових джерел походження рослинних білків та амінокислот, які можна буде застосувати для розширення асортименту вітчизняних біологічно активних добавок i лікарських засобів [11-12].

Найраціональнішим, на нашу думку, є пошук таких джерел у рослинній сировині флори України.

Мета дослідження - вивчити якісний склад і кількісний вміст вільних та зв'язаних амінокислот у траві та коренях самосилу гайового (Teucrium chamaedrys L.) та самосилу гірського (Teucrium montanum L.).

Матеріали та методи. Рослинну сировину представників роду Теисrium було заготовлено на території Солом'янського району міста Києва в період цвітіння (травні - червні 2019 року).

Для підтвердження якісного та визначення кількісного складу суми вільних і зв'язаних амінокислот використовували методику, запропоновану Штейном і Муром у сучасній модифікації, зі застосуванням автоматичного аналізатора амінокислот моделі ААА Т - 339 (Чехія).

Точну наважку сировини 0,1 г, подрібненої до розміру 1-2 мм, вміщували в герметичну гідролізну пробірку та піддавали кислотному гідролізу 6 М розчином кислоти хлористоводневої в термостаті за температури $+105{ }^{\circ} \mathrm{C}$ протягом 24 год. Ампулу розкривали, надлишок кислоти хло-

(c) Колектив авторів, 2021 
ристоводневої відганяли за температури $100{ }^{\circ} \mathrm{C}$ і подальшу нейтралізацію проб проводили в ексикаторі над натрієм гідроксидом протягом 2 діб. Пробірку охолоджували, досліджуваний розчин фільтрували в колбу зі шліфом та упарювали за допомогою ротаційного випарювача під вакуумом за температури водяного нагрівника $40{ }^{\circ} \mathrm{C}$. Сухий залишок розчиняли в цитратному буферному розчині (pH 2,2) та піддавали аналізу на автоматичному аналізаторі амінокислот.

Розподіл компонентів здійснювали на аналітичній колонці, яку заповнювали катіонітом LG ANB. Для виділення окремих амінокислот використовували три цитрат-натрієві буферні розчини.

Елюат, який виходив 3 колонки, змішувався 3 нінгідриновим реагентом у реакторі за температури $135{ }^{\circ} \mathrm{C}$, де проходила реакція між нінгідрином й амінокислотами з утворенням забарвлених сполук, кількість яких прямо пропорційна кількості амінокислоти в елюаті [13].

Суміш надходила до фотометра, де вимірювалася інтенсивність поглинання забарвленої сполуки за довжини хвилі 520 нм. Вихідний сигнал фотометра надходив на двоканальний самописець, який реєстрував концентрації амінокислот на хроматографі у вигляді серії піків. Час утримання піка, який визначали за хроматограмою, характеризує кожну індивідуальну амінокислоту. Площа піка відповідає концентрації присутньої амінокислоти.

Електричний сигнал самописця поступав на інтегратор, який автоматично обчислював площу кожного піка.

Кількісний вміст розраховували за калібрувальним графіком.

Результати та ї обговорення. Результати дослідження амінокис- лотного складу трави та коренів Teucrium chamaedrys L. i Teucrium montanum L. відображені в таблиці.

Отримані дані свідчать про наявність у всіх зразках досліджуваної рослинної сировини 18 амінокислот, 3 яких 7 є незамінними.

Відповідно до результатів дослідження визначено, що найбільшу кількість амінокислот містить трава Teucrium chamaedrys L. - 7,161 мг/ 100 мг. Вміст амінокислот у коренях самосилу гайового та траві самосилу гірського практично однаковий 3,853 мг/100 мг і 3,703 мг/100 мг відповідно. Найменша кількість амінокислот міститься в коренях самосилу гірського - 2,391 мг/100 мг.

Враховуючи дані таблиці, можна розташувати амінокислоти в наступній послідовності за зменшенням їхнього вмісту:

- трава Teucrium chamaedrys L.: глутамінова кислота > аспарагінова кислота $>$ лейцин $>$ гліцин $>$ лізин $>$ фенілаланін $>$ аланін $>$ тирозин $>$ гістидин $>$ валін $>$ серин $>$ треонін $>$ ізолейцин $>$ аргінін $>$ метіонін > пролін > цистин > ГАМК;

- корені Teucrium chamaedrys L.: аспарагінова кислота > глутамінова кислота > аланін > лейцин $>$ серин $>$ лізин $>$ гліцин $>$ тирозин $>$ треонін $>$ пролін $>$ аргінін $>$ валін $>$ фенілаланін $>$ ізолейцин $>$ гістидин $>$ метіонін $>$ ГАМК $>$ цистин;

- трава Teucrium montanum L.: аспарагінова кислота > глутамінова кислота $>$ лейцин $>$ лізин $>$ аланін $>$ гліцин $>$ серин $>$ треонін $>$ аргінін $>$ фенілаланін $>$ пролін $>$ тирозин $>$ валін $>$ ізолейцин $>$ гістидин $>$ метіонін $>$ цистин $>$ ГАМК;

- корені Teucrium montanum L.: аспарагінова кислота > глутамінова кислота $>$ серин $>$ аланін $>$ лейцин $>$ пролін $>$ треонін $>$ гліцин $>$ 


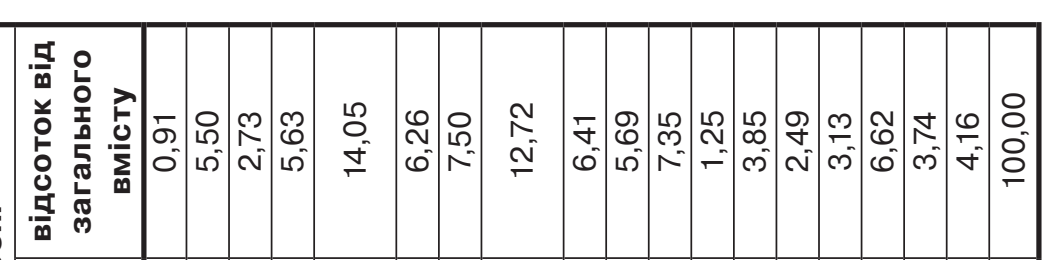

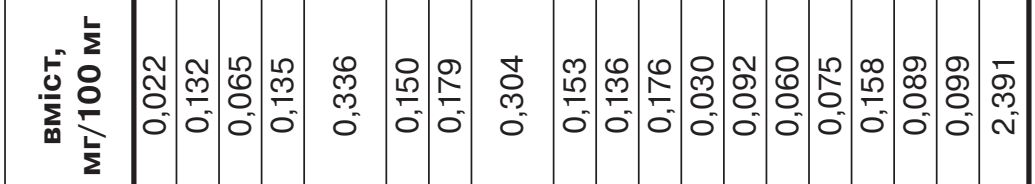

동 은

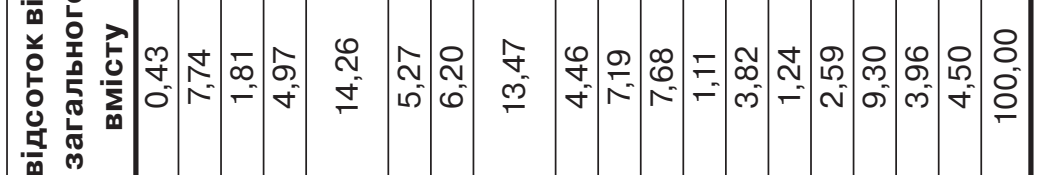
은

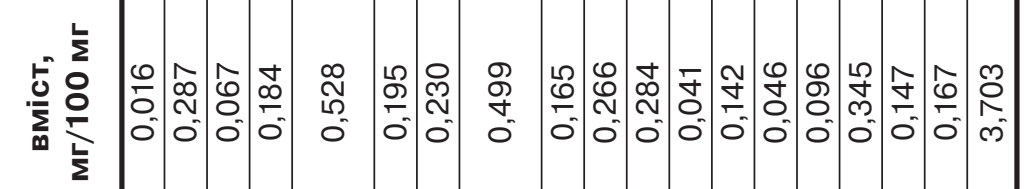

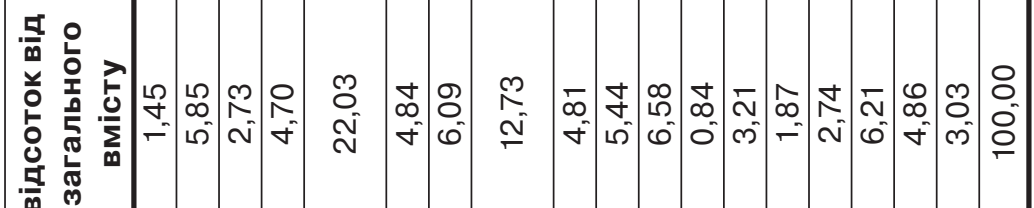

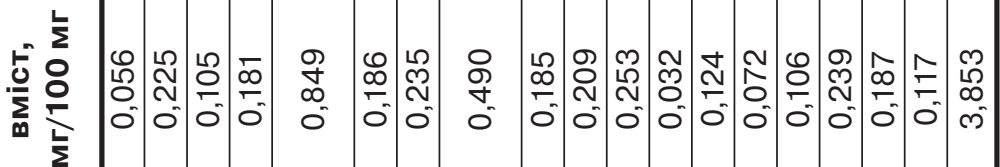

$$
\begin{aligned}
& \text { 동 은 } \\
& \text { ํㅜㄹ }
\end{aligned}
$$

ецочэихон!พ甘

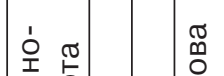

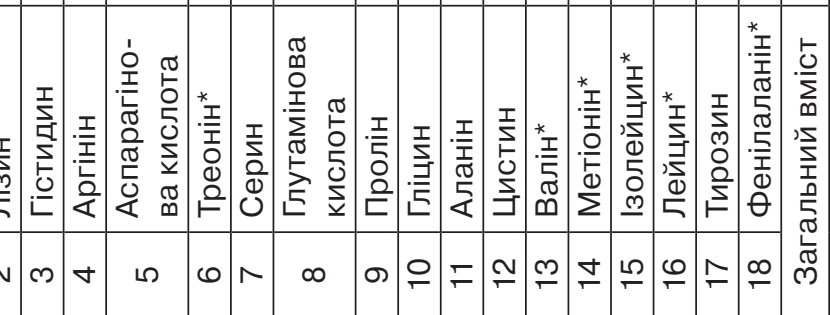


аргінін > лізин > фенілаланін > валін $>$ тирозин $>$ ізолейцин $>$ гістидин > метіонін > цистин > ГАМК.

У найбільшій кількості в траві та коренях Teucrium montanum $L$. i коренях Teucrium chamaedrys $L$. виявлено аспарагінову кислоту 0,528 мг/100 мг, 0,336 мг/100 мг та 0,849 мг/100 мг відповідно, тоді як у траві Teucrium chamaedrys $L$. домінуючим компонентом є глутамінова кислота.

Серед переважаючих амінокислот, окрім аспарагінової та глутамінової кислот, варто відзначити лейцин, гліцин, лізин та аланін, концентрація яких у досліджуваних об'єктах у межах 5-10 \% від загального вмісту амінокислот.

У траві самосилу гайового серед мажоритарних компонентів виявлено 0,653 мг/100 мг лейцину, 0,606 мг/ 100 мг гліцину, 0,543 мг/100 мг лізину та 0,361 мг/100 мг аланіну. У коренях самосилу гайового концентрація даних амінокислот становить 0,239 мг/100 мг, 0,209 мг/100 мг, 0,225 мг/100 мг та 0,253 мг/100 мг відповідно.

У траві самосилу гірського визначено 0,345 мг/100 мг лейцину, 0,266 мг/ 100 мг гліцину, 0,287 мг/100 мг лізину та 0,284 мг/100 мг аланіну. Вміст даних амінокислот у коренях само- силу гірського становить 0,158 мг/ $100 \mathrm{мг,} \mathrm{0,136} \mathrm{мг/100} \mathrm{мг,} \mathrm{0,132} \mathrm{мг/100} \mathrm{мг}$ та 0,176 мг/100 мг відповідно.

У найменших кількостях у всіх досліджуваних об'єктах виявлено метіонін, цистин і гамма-аміномасляну кислоту.

Таким чином, варто зазначити, що результати проведених досліджень розширюють відомі дані про амінокислотний склад трави та коренів Teucrium chamaedrys L. i Teucrium montanum L., які можна використовувати для розробки методик аналізу лікарських препаратів на основі даної рослинної сировини.

\section{Висновки}

1. Вивчено якісний склад і кількісний вміст амінокислот у траві та коренях Teucrium chamaedrys L. i Teucrium montanum $L$.

2. Отримані дані свідчать про наявність у всіх зразках досліджуваної рослинної сировини 18 амінокислот, з яких 7 є незамінними.

3. У найбільшій кількості в рослинній сировині присутні аспарагінова та глутамінова кислота.

4. Відповідно до результатів дослідження було визначено, що найбільшу кількість амінокислот містить трава Teucrium chamaedrys L. 7,161 мг/100 мг.

1. Володимирець В. І. Біохімія рослин: Інтеративний комплекс навчально-методичного забезпечення. Рівне : НУВГП, 2006. 127 с.

2. Амінокислотний склад трави Polygonum hydropiper L. та Polygonum persicaria L. флори України. І. А. Лукіна, О. В. Мазулін, Г.П.Смойловська та ін. Актуальні питання фармацевтичної і медичної науки та практики. 2015. № 1 (17). С. 56-59.

3. Амінокислотний склад трави перспективних видів роду Оман (Inula L.) флори України. О. К. Єренко, О. В. Мазулін, Г. П. Смойловська та ін. Фармацевтичний журнал. 2012. № 3. С. 94-98.

4. Мазулін О. В., Калошина Н. А., Денисенко О. Н. Амінокислотний склад - важлива характеристика біологічної активності лікарської сировини. Актуальні питання фармац. та мед. науки та практики: зб. наук. ст. Запоріжжя : Вид-во ЗДМУ, 1999. Вип. IV. С. 36-38.

5. Смойловская Г. П., Мазулин А. В., Гречаная Е. В. Содержание аминокислот в видах рода Achillea L. флоры Украины. Запорожский медицинский журнал. 2008. T. 2, № 47. С. 135-136.

6. Кисличенко В. С. Системная фитотерапия: учеб. пособие для студ. вузов; под ред. В. С. Кисличенко, А. В. Зайченко, И. А. Журавель. Харьков : Изд-во НФаУ: Золотые страницы, 2008. 256 с.

7. Кобзар А. Я. Фармакогнозія в медицині: навч. посіб. Київ : Медицина, 2007. 543 с.

8. Губський Ю. І. Біологічна хімія. Вінниця : Нова книга, 2007. 656 с. 
9. Западнюк В. И., Кураш Л. П., Заика М. И. Аминокислоты в медицине. Киев : Здоров'я, 1982. $200 \mathrm{c}$.

10. Davies J. S. Aminoacids, peptides and proteins. Cambridge : The Royal Society of Chemistry, 2006. $472 \mathrm{p}$.

11. Делян Є. П. Амінокислотний склад надземних органів рослин роду Sonchus. Фармакологія та лікарська токсикологія. 2016. № 1. С. 102-106.

12. Зоценко Л. О., Цуркан О. О. Амінокислотний склад надземних органів Elsholtzia Stauntonii benth. Збірник наукових праць співробітників НМАПО ім. П. Л. Шупика. 2017. Вип. 28. С. 51-57.

13. Использование нингидриновой реакции для количественного определения б-аминокислот в различных объектах : методические рекомендации. А. В. Симонян, А. А. Саламатов, Ю. С. Покровская, А. А. Аванесян. Волгоград, 2007. 106 с.

\section{К. М. Анзіна, А. В. Гудзенко \\ Амінокислотний склад трави та коренів деяких перспективних рослин роду Teucrium L. флори України}

Потреба людини в рослинному білку, перш за все, пов'язана з важливістю надходження амінокислот. Наявність дефіциту принаймні однієї незамінної амінокислоти робить раціон харчування людини неповноцінним, що може стати причиною розвитку ряду патологічних станів організму.

Виходячи з цього, одним з актуальних питань сучасної фармації є пошук нових джерел походження рослинних білків та амінокислот, які можна буде застосувати для розширення асортименту вітчизняних біологічно активних добавок і лікарських засобів.

Мета дослідження - вивчити якісний склад і кількісний вміст вільних і зв'язаних амінокислот у траві та коренях самосилу гайового (Teucrium chamaedrys L.) і самосилу гірського (Teucrium montanum L.).

Для визначення суми амінокислот використовували методику, запропоновану Штейном і Муром у сучасній модифікації, зі застосуванням автоматичного аналізатора амінокислот моделі ААА Т - 339 (Чехія).

Попередньо підготовану наважку сировини розчиняли в цитратному буферному розчині та піддавали аналізу. Розподіл компонентів здійснювали на аналітичній колонці, яку заповнювали катіоніToм LG ANB. Для реєстрації амінокислот використовували метод детекції нінгідрином.

Отримані дані свідчать про наявність у всіх зразках досліджуваної рослинної сировини 18 амінокислот, з яких $7 €$ незамінними.

Найбільша кількість амінокислот міститься у траві Teucrium chamaedrys L. - 7,161 мг/100 мг. Вміст амінокислот у коренях самосилу гайового та траві самосилу гірського практично однаковий 3,853 мг/ 100 мг та 3,703 мг/100 мг відповідно. Найменша кількість амінокислот міститься у коренях самосилу гірського - 2,391 мг/100 мг.

У найбільшій кількості в рослинній сировині присутні аспарагінова та глутамінова кислоти. Серед переважаючих амінокислот варто відзначити лейцин, гліцин, лізин та аланін, концентрація яких у досліджуваних об'єктах складає 5-10 \% від загального вмісту амінокислот.

Результати проведених досліджень розширюють існуючі відомості про амінокислотний склад трави та коренів Teucrium chamaedrys L. і Teucrium montanum L.

Ключові слова: амінокислоти, високоефективна рідинна хроматографія, рід Teucrium L.

\section{Е. Н. Анзина, А. В. Гудзенко}

\section{Аминокислотный состав травы и корней некоторых перспективных растений рода Teucrium L. флоры Украины}

Потребность человека в растительном белке, прежде всего, связана с важностью поступления аминокислот. Наличие дефицита, по крайней мере, одной незаменимой аминокислоты делает рацион питания человека неполноценным, что может стать причиной развития ряда патологических состояний организма.

Исходя из этого, одним из актуальных вопросов современной фармации является поиск новых источников происхождения растительных белков и аминокислот, которые можно будет применить для расширения ассортимента отечественных биологически активных добавок и лекарственных средств.

Цель исследования - изучить качественный состав и количественное содержание свободных и связанных аминокислот в траве и корнях дубровника обыкновенного (Teucrium chamaedrys L.) и дубровника горного (Teucrium montanum L.).

Для определения суммы аминокислот использовали методику, предложенную Штейном и Муром в современной модификации, с применением автоматического анализатора аминокислот модели ААА Т - 339 (Чехия).

Предварительно подготовленную навеску сырья растворяли в цитратном буферном растворе и подвергали анализу. Распределение компонентов осуществляли на аналитической колонке, которую заполняли катионитом LG ANB. Для регистрации аминокислот использовали метод детекции нингидрином. 
Полученные данные свидетельствуют о наличии во всех образцах исследуемого растительного сырья 18 аминокислот, из которых 7 являются незаменимыми.

Наибольшее количество аминокислот содержится в траве Teucrium chamaedrys L. - 7,161 мг/100 мг. Содержание аминокислот в корнях дубровника обыкновенного и траве дубровника горного практически одинаково 3,853 мг/100 мг и 3,703 мг/100 мг соответственно. Наименьшее количество аминокислот содержится в корнях дубровника горного - 2,391 м/100 мг.

В наибольшем количестве в растительном сырье присутствуют аспарагиновая и глутаминовая кислоты. Среди преобладающих аминокислот стоит отметить лейцин, глицин, лизин и аланин, концентрация которых в исследуемых объектах составляет 5-10 \% от общего содержания аминокислот.

Результаты проведенных исследований расширяют существующие сведения об аминокислотном составе травы и корней Teucrium chamaedrys L. и Teucrium montanum L.

Ключевые слова: аминокислоты, высокоэффективная жидкостная хроматография, род Tеucrium L.

\section{K. Anzina, A. Gudzenko \\ Amino acid composition of herbs and roots of some perspective plants of the genus Teucrium $L$. of Ukrainian flora}

The human need for plant proteins is associated with the importance of amino acids intake. The deficiency of at least one essential amino acid makes a person's diet poor, which can lead to the development of many pathological conditions.

Based on this, one of the topical issues of modern pharmacy is the search for new sources of plant proteins and amino acids that can be used to expand the range of biologically active supplements and drugs.

The aim of the work is to determine the qualitative and quantitative composition of amino acids in the grass and roots of Teucrium chamaedrys $L$. and Teucrium montanum $L$.

To determine the number of amino acids, we used the technique proposed by Stein and Moore in a modern modification, using an automatic amino acid analyzer of the AAA T - 339 model (Czech Republic).

A pre-prepared sample was dissolved in a citrate buffer solution and subjected to analysis. The distribution of the components was carried out on an analytical column, which was filled with an LG ANB cation exchanger. For registration of amino acids, the ninhydrin detection method was used.

The data obtained indicate the presence of 18 amino acids in all samples of the plant materials, 7 of which are essencial.

The largest amount of amino acids was found in the grass of Teucrium chamaedrys L. $-7.161 \mathrm{mg} / 100 \mathrm{mg}$. The amino acid content in the roots of Teucrium chamaedrys $L$. and grass of Teucrium montanum $L$. is almost the same $3.853 \mathrm{mg} / 100 \mathrm{mg}$ and $3.703 \mathrm{mg} / 100 \mathrm{mg}$, respectively. The smallest amount of amino acids is found in the roots of Teucrium montanum L. $-2,391 \mathrm{mg} / 100 \mathrm{mg}$.

Aspartic and glutamic acids are present in the largest quantities in samples. Among the predominant amino acids, it is worth noting leucine, glycine, lysine and alanine, the concentration of which in the objects is in the range of $5-10 \%$ of the total amino acid content.

The results of the investigation expand the existing information about the amino acid composition of the grass and roots of Teucrium chamaedrys $L$. and Teucrium montanum $L$.

Key words: amino acids, high-performance liquid chromatography, genus Teucrium L.

\section{ORCID ID співавторів:}

Анзіна К. М. (ORCID ID 0000-0003-0891-1856);

Гудзенко А. В. (ORCID ID 0000-0001-6015-2266).

Надійшла: 13 жовтня 2021 р.

Прийнята до друку: 8 грудня 2021 р.

Контактна особа: Гудзенко Андрій Вікторович, доктор фармацевтичний наук, кафедра хімії ПВНЗ «Київський медичний університет», буд. 2, вул. Бориспільська, м. Київ, 02099. Тел.: + 380633418547. Електронна пошта: ganvi75@gmail.com 